\title{
Technology and Trade at Ancient Gordion: Insights from Microanalysis of First Millennium BCE Glass
}

\author{
W.J. Reade, ${ }^{*}$ J. Duncan Jones, ${ }^{* *}$ and K.L. Privat*** \\ * Centre for Classical and Near Eastern Studies of Australia, University of Sydney, Camperdown \\ NSW 2006, Australia \\ ** Classics Department, Bucknell University, Lewisburg, PA 17837 \\ *** Electron Microscope Unit, University of New South Wales, Kensington NSW 2052, Australia
}

In the first half of the first millennium BCE, the ancient city of Gordion, in central Anatolia, was the capital of the kingdom of Phrygia. Still famous as the home of King Midas, Gordion was situated on major east-west trade routes and arterial rivers, and provided a link between surrounding Near Eastern states and between these states and the Greek world further to the west. Excavations at Gordion have yielded a number of monochrome glass objects, mainly vessels, from the Phrygian period (Iron Age, $9^{\text {th }}-7^{\text {th }}$ c. BCE) and later Hellenistic period (mid- $4^{\text {th }}$ to early $2^{\text {nd }}$ c. BCE). We undertook electron microprobe analysis (WDS) of a set of 51 glass samples from Phrygian, Hellenistic and undated contexts at Gordion in order to examine similarities and differences among glass of the two periods, and to investigate broader technological and economic relationships between Phrygian and Hellenistic Gordion and its neighbors.

Analyses were conducted using a JEOL JXA-8500F electron microprobe at the University of New South Wales $(15 \mathrm{kV}, 15 \mathrm{nA} \& 30 \mu \mathrm{m}$ probe diameter). Calibration and accuracy assessment were performed using standard minerals and glasses of known composition. Total analytical error for the analyses was $\leq \pm 2 \%$ relative for elements $>1 \mathrm{wt} \%$ (except $\mathrm{Al}_{2} \mathrm{O}_{3}< \pm 5 \%$ relative), and $\leq \pm 6 \%$ for elements present near the detection limits of 100-400ppm. The chemical analyses showed the Gordion glasses to be soda-lime-silica glasses, mainly of high-magnesia, high-potash composition $(\mathrm{HMHK}=15)$, or of low-magnesia, low-potash type (LMLK=33). HMHK glasses $\left(\mathrm{MgO} \& \mathrm{~K}_{2} \mathrm{O}\right.$ approximately $>1.5 \%$ ) are generally indicative of the use of a plant ash flux in manufacture [1], while LMLK glasses tend to be associated with glass manufacture employing a mineral soda flux, such as natron. The earlier, Phrygian glasses are mainly of HMHK composition, while all 22 dated Hellenistic glasses are of LMLK composition. The greater compositional variability of the Phrygian HMHK glasses (particularly in magnesia, potash, lime \& phosphate) may be due to the variability of the composition of the plant ashes used in the manufacture of these glasses, relative to the presumably more consistent composition of the mineral flux used in the LMLK glass manufacture. Differences between Phrygian and Hellenistic period LMLK glasses can be seen in the alumina and iron oxide concentrations, which suggest different silica sources for these two groups.

Compositions of Phrygian HMHK glasses from Gordion were compared to those of HMHK glasses from Bronze Age Nuzi in Iraq (Reade, unpub. data) and Pella in Jordan [2], and from Iron Age Nimrud in Iraq [3]. While most of the HMHK Gordion glasses exhibit compositions similar to those of the Iron Age Nimrud glasses, four Gordion samples are chemically more similar to the Bronze Age Near Eastern glasses of relatively higher potash concentrations, suggesting the possibility of two distinct groups of HMHK glass at Phrygian Gordion. 
Compositions of non-Hellenic LMLK glasses from Gordion were compared with those of LMLK glasses from $10^{\text {th }}-8^{\text {th }}$ century sites in Egypt [4], Jordan [3] and Iraq (Assyria) [3]. The chemical variability of the Gordion glasses lies within the range of the Near Eastern/Egyptian glasses. A sample from an elaborately designed, moulded glass Phrygian bowl, along with three Phrygian LMLK and another ungrouped glass, group tightly in potash and magnesia with Assyrian glasses and some of the Egyptian glasses. The close chemical similarities of the moulded bowl and related specimens with the Near Eastern/Egyptian glasses reinforce the hypothesis made by von Saldern that the moulded glass bowls from Gordion represent imports of Near Eastern origin [5].

Of the coloured glass specimens from Gordion, the single dark blue glass (a bead) is colored with cobalt, and exhibits close chemical similarities with $1^{\text {st }}$ millennium BCE Nimrud cobalt blue glasses [3] as well as $2^{\text {nd }}$ millennium BCE Egyptian glasses of the same color [6,7]. Similar to earlier Bronze Age Near Eastern and Egyptian colorless glasses [e.g.,7,8], the colorless Phrygian glasses from Gordion do not contain appreciable quantities of decolorant. In contrast, the majority of colorless glasses from Hellenistic contexts at Gordion contain antimony as a decoloring agent (1.0-5.8\%). Three of the Gordion colorless glasses appear to have been decolored using manganese ( $\mathrm{MnO}$ of $0.4-$ $0.6 \%, \mathrm{Sb}_{2} \mathrm{O}_{3}<0.6 \%$ ); these specimens may be some of the earliest examples for the use of manganese as a decolorant.

The two main types of glass identified at Gordion reflect differences in raw materials used in glass manufacture. The close compositional similarities of Gordion Phrygian glasses with glasses from Bronze Age and Iron Age Near Eastern sites strongly suggests that Phrygian glass at Gordion did not originate locally, but was imported from the Near East. While raw glass production may not have taken place locally, the distinctly Phrygian style of some of the glass vessels found at Gordion suggest that raw glass may have been imported and worked at Gordion. The chemical and stylistic analyses of Gordion glass do not provide evidence for local glass production at Gordion, but mark out the Phrygians and their successors as likely glassworkers. The limited data suggest the importation and/or working of HMHK glass in the Phrygian period, with a shift in the Hellenistic period toward LMLK glass of more tightly controlled production than earlier Near Eastern and Egyptian LMLK glass [9].

References

[1] R.H. Brill. Chemical Analyses of Early Glasses, Vol.1: Catalogue of Samples, Corning Museum of Glass, New York, 1999.

[2] W.J. Reade et al., Ann. 17 Congr. Assoc. Int. Hist. Verre 2006 (2009) 47.

[3] W.J. Reade et al., Ann. 16 Congr. Assoc. Int. Hist. Verre 2003 (2005) 39.

[4] B. Schlick-Nolte \& R. Werthmann, J. Glass Stud. 45 (2003) 11.

[5] A. von Saldern, J. Glass Stud. 1 (1959) 23.

[6] A. Kaczmarczyk, Proc. 24 Int. Archaeom. Sym. (1986) 369.

[7] M.T. Wypyski in C. Lilyquist et al., Studies in Early Egyptian Glass, Metropolitan Museum of Art, New York, 1993.

[8] E.V. Sayre, VI International Congress on Glass: Advances in Glass Technology, Part 2, Plenum Press, New York, 1963.

[9] Thanks to G. Kenneth Sams \& Mary Voigt for support \& access to funds; to The Loeb Library Foundation, Council of Overseas Research Centers \& Bucknell University for funding; to UNSW for instrument access \& travel funding for KLP; \& to Despina Ignatiadou. 